\title{
Nile Crossings: Hospitality and Revenge in Egyptian Rural Narratives
}

\section{Citation}

Granara, William E. 2010. Nile Crossings: hospitality and revenge in Egyptian rural narratives. Journal of Arabic Literature 41(1-2): 121-135.

\section{Published Version}

doi:10.1163/157006410X486765

\section{Permanent link}

http://nrs.harvard.edu/urn-3:HUL.InstRepos:9882639

\section{Terms of Use}

This article was downloaded from Harvard University's DASH repository, and is made available under the terms and conditions applicable to Other Posted Material, as set forth at http:// nrs.harvard.edu/urn-3:HUL.InstRepos:dash.current.terms-of-use\#LAA

\section{Share Your Story}

The Harvard community has made this article openly available.

Please share how this access benefits you. Submit a story.

Accessibility 


\title{
Nile Crossings: Hospitality and Revenge in Egyptian Rural Narratives
}

\author{
William Granara \\ Harvard University
}

\begin{abstract}
This essay looks at acts of hospitality and revenge as constituent elements of a broad social code in rural Egyptian narratives. By looking at five stories in particular, I argue that hospitality and revenge work in complementarity, and that they often trespass and blur each other's social and literary borders, creating ambiguity and complexity in the stories. The traditional rules that govern hospitality are at times challenged or inverted by hostile intentions, and revenge may be exacted for common or personal well-being. Also, the Nile River, richly symbolic of Egyptian history and identity, plays a vital role in situating the self, in all its pristine, bifurcated, and sullied forms.
\end{abstract}

\section{Keywords}

Egyptian short story; revenge; hospitality; Nile; identity

Hospitality cuts across geographical spaces and historical eras and manifests itself in a multitude of similar and different ways. Whether practiced at the individual or familial level, or at the extended collective level, tribal, regional, sectarian or national, it tells us much about the ways in which the self sees itself and views the other. In American society, 'Southern hospitality' conjures a host of images that span a traditional way of life: an idyllic pastoral landscape, easy living, urbane gentility and refined manners, and, above all, warmth and generosity toward the guest or stranger. Implied in this imagery is the cold, impersonal North in which humanity is lost in the chaos of rapid change, forced integration, and the struggle to eke out a living in an impersonal urban environment. Hospitality is thus encoded with social

For Roger Allen,

Teacher, mentor, colleague and friend 
significances that touch on the political, and very often targets the tensions that lie as much within the bifurcated self as in interactions with outsiders. Modern Arabic literature, which reads particularly close to contemporary historical realities and events, is replete with examples of hospitality that likewise conjure a host of images heavily encoded with political and social meaning.

This essay is based on a reading of five short stories, ranging from 1954 to 1970, which draw on the rural landscape of Upper Egypt (and the Delta) and which, in varying ways and to varying degrees, foreground themes of hospitality. Like the 'old' American South and other tradition-oriented societies, hospitality plays a significant role in rural Egyptian society. But as my proof-texts will show, hospitality is a far more complicated matter than offering food and drink to a guest. Very often we find scenes of hospitality marred by hostile people or actions, instigated by a desire or obligation for revenge. I use my reading of Derrida's essays in Of Hospitality to help articulate the complexity of this seemingly simple social phenomenon. ${ }^{1} \mathrm{~A}$ key point emphasized by Derrida is his evocation of the Latin term hostis, from which both 'host' and 'hostile' derive, implying that the foreigner may be welcomed as a guest or as an enemy, thus establishing a link to the concepts of hospitality and hostility. ${ }^{2}$

This curious linkage is reminiscent of Amitav Ghosh's In An Antique Land (1992) and of how the warm reception of the author/narrator/protagonist's status as a welcome guest in an Egyptian village is frequently disturbed by suspicion and hostility. In the course of his narration, Ghosh reveals himself as the consummate foreigner who, as Derrida puts it, "doesn't understand the legal language in which the duty of hospitality is formulated, and who is always at risk of being without defense before the law of the country that welcomes or expels him."' What concerns me here is Derrida's assertion that "the law of hospitality appears as a paradoxical law, pervertible or perverting," 4 thus leading one to "become virtually xenophobic in order to protect, or claim to protect, one's own hospitality," and it is the home that makes possible one's hospitality. It is the "constant collusion between traditional hospitality and power," as Derrida observes, that underscores the major thrust of my argument. ${ }^{5}$

My line of inquiry is two-pronged. First, I argue that 'hospitality' and 'revenge' are constituent parts of a broad social code that work in comple-

\footnotetext{
${ }^{1}$ Jacques Derrida, Of Hospitality: Anne Dufourmantelle invites Jacques Derrida to respond, $\mathrm{tr}$. Rachel Bowlby (Stanford: Stanford University Press, 2000).

${ }^{2}$ Derrida, Of Hospitality, pp. 39-45.

3 Derrida, Of Hospitality, p. 15.

${ }^{4}$ Derrida, Of Hospitality, p. 25.

5 Derrida, Of Hospitality, p. 55.
} 
mentarity, often trespassing and blurring each other's social and literary borders in order to convey ambiguity and complexity. The traditional rules and customs that govern hospitality are at times challenged or inverted by hostile intentions, by suspicion, by a desire to respond in kind or get even, or merely by fear itself. Similarly, revenge may be exacted for the common good, for survival, for self-protection or advancement, or simply to restore balance and equity among individuals or groups. I should state from the outset that I do not intend to generalize that all acts of hospitality are tinged with hostility, or that all acts of revenge are well-intentioned; I do not subscribe to an organic relationship between the two. Hospitality is a value deeply rooted in traditional Bedouin (and pan-Mediterranean) customs of greeting the guest, and has been inscribed into Islamic ethos and law in the form of 'alms for the poor' (zakāt, sadaqah), and the extension of a helping hand to the wayfarer (ibn al-sabil). Medieval Arabic adab, moreover, both as a social and literary movement, expanded beyond the traditional nomadically circumscribed boundaries of hospitality to encompass urban civility and urbane refinement, where host/guest comportment and interaction, subjected to societal rules, took on greater cultural, and textual signification(s). However, the very nature of hospitality, as Derrida points out, assumes an element of power, a kind of hierarchy where sovereignty "can only be exercised by filtering, choosing, and thus by excluding and doing violence." ${ }^{\text {I }}$ do subscribe to Andrew Shyrock's definition in his study of Jordanian host/guest relationships that "hospitality is a field of ritualized exchange in which performance animates and responds to social critique, and that acts undertaken in this field must be carefully orchestrated to protect against the 'private or open warfare' that is their built- in sanction." 7

Second, I will show how the Nile River, in all its explicit or implied imagery, functions as a powerful signifier in the group of short stories on which I focus. My contention is that the Nile's ominous presence in these stories delineates all sorts of boundaries, from the narratological to the national, unleashing a gamut of psychological, religious, social and political meanings that are both horizontally and vertically grafted throughout the texts. More specifically, images of floating along the Nile very often reinforce normative behavior and tradition, while images of crossing the Nile subvert or contest them.

Two seminal anthropological studies are important to my reading of the themes of hospitality and revenge in these stories. French sociologist Marcel

${ }^{6}$ Derrida, Of Hospitality, p. 55.

7 Andrew Shryock, "The New Jordanian Hospitality: House, Host and Guest in the Culture of Public Display," Comparative Studies in Society and History 46 (2004), pp. 35-62. 
Mauss's groundbreaking work, The Gift, offers two points central to my argument: (1) that a gift is part of a system of reciprocity in which the honor of giver and recipient is engaged, leading to a perpetual cycle of exchanges that engage persons in permanent commitments; and (2) that gifts are given in the context of public drama, with nothing secret about them, and are directly cued to public esteem, the distribution of honor, and the sanction of religion. ${ }^{8}$ Mauss also makes the following observations: (3) It is not individuals but collectivities (clans, tribes, families) that impose obligations of exchange and contract upon each other; (4) Exchanges are not solely property and wealth, but acts of politeness, banquets, rituals, military services, women, children, dances, festivals; (5) These "total services" are committed to in a voluntary form but are strictly compulsory: to refuse to give, to fail to invite, and to refuse to receive are tantamount to declaring war (exchanging presents puts the seal upon marriage and form the link of kinship between the two families, balancing the competition, rivalry, between the two); (6) The notion of honor plays a pivotal role in the gift and the way (in degree and amount) it is presented: there is an obligation to voice appreciation, for by accepting, one acknowledges that one has committed oneself.

Several of the conclusions of Ahmad Abū Zayd's ethnographic study of rural Egyptian society are also pertinent:" (1) Revenge (tha'r) flourishes in tribal systems where kinship (al-qarābah) and group solidarity (al-'așabiyyah) play a central role; (2) Peoples and families live on a relatively equal socioeconomic plane which makes revenge all the more compelling, especially in the absence of a hierarchal system that would impose its will; (3) Revenge assumes that the village is a self-contained unit, one that privileges the patriline over the matriline, and that emphasizes seniority in its power structure; (4) Revenge abounds in a social group whose members lean on each other in times of crisis - especially when crimes are committed against someone in the group — and who are bound by mutual rights and duties ( huqqūq wa wājibāt); (5) Women play no active role in exacting revenge, nor are they targets of revenge; (6) Elders have the final say in exacting revenge, and thus are often the prime victims of revenge in that their demise causes great havoc in the family of the perpetrators; (7) Christians, weak but not necessarily impoverished, do not get involved in revenge with Muslims: they are better educated, they remain neutral, and they seek the protection of larger Muslim families;

${ }^{8}$ Marcel Mauss, Essai sur le Don, Forme et Raison de l'Echange dans les Sociétés archaiques (Paris: Alcan, 1925); English translation: The Gift: forms and functions of exchange in archaic societies, tr. W. D. Halls (London: Routledge, 1990).

${ }_{9}$ Aḥmad Abū Zayd, al-Thàr: dirāsah anthrüpülüjiyyah bi-iḥdā qurā al-sa'id (Cairo: Dār al-Ma àrif, 1965). 
(8) Taking revenge to regain social standing (shakhsiyyah ijtimäiyyah) is the only mechanism for setting things right ( $d a b t)$ in the presence of a weak provincial (or national) government.

\section{II}

The Arabic novel in Egypt provides us with a treasure trove of stories that delve into the complex and intertwining relationship between hospitality and revenge. Taha Husayn's al-Ayyäm (1929) offers the scene of his family stretching its meagre resources to provide a sumptuous feast in order to conceal their loathing and contempt for a charlatan Sufi shaykh who descends upon the village year after year. Yūsuf Idrīs's al-Harām (1965) uses conflicting images of hospitality and hostility in illustrating the contentious relationship and bitter rivalry between sedentary villagers ( fallāhīn) and itinerant migrant workers (al-tarāḥil) in an Egyptian village. Sulaymān Fayyāọ’s Așwāt (1972) brings the binary topos of hospitality and hostility into the response of the village women to the infractions of village customs committed by the 'foreign' wife of one of its prodigal sons in an epic account of East-West cross-cultural conflict. 'Abd al-Hakīm Qāsim's al-Mahdī (1984) constructs the story of an assertive group of village 'brethren' who extend a helping hand to an impoverished Coptic Christian umbrella maker, only to coerce him into accepting Islam in a public display that reworks much of the passion and imagery of the crucifixion of Christ. Perhaps the most stunning example of the hospitality/revenge pairing appears in Bahā' Țāhir's Khālatì Șafiyya wal-Dayr (1991) in which the narrator's childhood voice recounts the tormented life of a village farmhand caught between the obsession for revenge and the sanctuary and hospitality of a Christian monastery. A love story goes awry as the would-be lover is coerced into marriage with another, a murder in self-defense takes place, and the pain of unrequited love morphs into an obsession for revenge, requiring all the villagers - a microcosm for Egyptian society, as it were-to take sides along the hospitality/revenge divide.

The Arabic short story also abounds in such re-workings of the hospitality/ hostility dialectic. Arguably the literary genre that most clearly resonates with the pulse of the nation, the short story, with its relatively early generic maturation and its efficacy in narrative realism, collapses in vivid detail through its artistic economy all the intricacies of the hospitality/hostility paradox. I begin my discussion of these short stories with two, very brief, narratives that contain all the constituent parts that inform my argument: hospitality, revenge and the ominous presence of the Nile River as the central artery of 
Egyptian life. While the first story represents something of a traditional paradigm, the second offers an example of its inversion, or to use Derrida's terminology, its pervertibility.

\section{Story 1. "Fāil khayr" ("Benevolence") by Șabrī Mūsā, $1970^{10}$}

A mother notices the flush and ripeness of her otherwise undernourished daughter, takes her aside, inspects her, and discovers she is three months pregnant. The girl confesses that a man raped her on a hill by the field. The mother's thoughts turn to her deceased husband and she laments his failure to give her a son, and then agonizes over what will happen when the daughter appears in the village. The next day, they stop by the river and the daughter washes her mother's face as she sits wailing.

A man passes by and sees the woman crying. He is big and strong (a familiar description of a sturdy falläb). He asks her what is wrong and she tells him. He is a professional robber and killer but takes pity on the woman. She takes him home, and in keeping with village custom, feeds him and puts him up for the night. He responds to her hospitality with comfort and assurance that all will be well. During the night he breaks the girl's neck and dumps her body in the Nile. In the morning, he assumes the role of host and prepares breakfast for the woman, then mounts her on a donkey and accompanies her into the village, her honor restored. The story ends with her silently thanking God for this man.

In "Benevolence" a crime has been committed, a crime of honor ( jarimat sharaf), but there is no man in the family to carry out the prescribed duty of revenge. The mother finds a solution in the passer-by who, through her hospitable acts of feeding him and providing him with shelter, becomes the surrogate husband, father, and avenger. The stranger, curiously constructed by the author as a dangerous criminal, accepts the hospitality and, along with it, the obligation to satisfy her revenge and restore the family's honor. The daughter's washing of the mother's tears, symbolic as an act of contrition, and her burial, both taking place on the banks of the Nile, bring the crime to its final resolution. The village universe has been restored to order along traditional lines of village custom and reader expectation.

${ }^{10}$ Șabrī Mūsā, "Fã̄il khayr," in Mashrü qatl jārah: riwāyāt șaghìrah (Cairo: al-Hay’ah al-'Āmmah lil-Kitāb, 1992), pp. 130-136; it first appeared in Ṣabāh al-khayr in 1970; English translation: "Benevolence," tr. Elizabeth Bloeger and Vivien Abadeer, ed. Anne Lillios, in Egyptian Tales and Short Stories of the 1970s and 1980s, ed. W. M. Hutchins (Cairo: American University in Cairo Press, 1987), pp. 56-58. 
During a dark night and sandstorm, a man crosses the Nile in a small fishing boat and is dropped off by the bank of a village. He sits, lights a cigarette and loads a cartridge into his rifle. He then follows the path along a palm grove and toward the village. He comes to the outskirts of the village (al-Misarah) for the first time in 20 years (even though it is close to his):

Hassān swore ever since his father was murdered while coming back from the souk never to set foot in that village until he had punished his father's killer and got his revenge. Hassān was the oldest son and it was incumbent upon him and him alone to wash away the blood that soiled the family and to remove its shame.

The problem is that his father's killer died of natural causes one month after the crime, leaving a twelve year old son, 'Abbās. Hassān wanted to kill him but his mother prevented him until the boy became old enough to carry a gun and protect himself, lest the feud become a joke among villagers. But with 'Abbās now of the age of maturity, Hassān begins to stalk him in his quest to perform his duty of revenge.

As he walks through the palm groves, he spots the dim light of a small farmhouse, and he sees a young boy standing in the doorway. He asks for something to drink and the mother comes out with a pitcher of water. The hospitality is layered with sexual tension as the woman unveils and scrutinizes him. Her attempts at hospitality and his quest for revenge converge as she engages him in conversation, seductively playing with her shawl, revealing pearly white teeth, luscious lips, a radiant face, responding to her longing for a male figure with the fear and suspicion of a stranger in her midst. Hassān thanks her and leaves, knowing that 'Abbās is now at a certain coffee house.

As the wind howls, leaves rustle, and dogs bark in the night, Hassān imagines graves opening and ghosts emerging. He worries that he won't kill him with the first shot but reassures himself that his rifle is of fine quality. Then he smells smoke, looks out and sees flames billowing in the sky. The fire spreads to the houses and the silos, consuming the grain as well. The villagers come together to put out the fire. He spots the woman in front of her house, screaming for help to save her son. A man dives into the flames and comes out carrying the little boy. When he sees the rescuer is 'Abbās, Hassān stoops down and removes the cartridge for his rifle, and the story ends with the

11 Maḥmūd al-Badawī, "al-Ramād," in al-Masǟ 1579 (1961), reprinted in Qiṣaṣ min al-rīf al-miṣrī al-ṣa ī $d \bar{\imath}$ (Cairo: Maktabat Miṣr: 2002), pp. 197-202. 
implication that Hassān will board the fishing boat to cross the Nile and return to his village.

"The Ashes" replicates the familiar paradigm constructed in "Benevolence," but ends on a different note. The crime and its prescribed duty of revenge needed to wait a generation until the perpetrator's kin came of age, as is the custom, but the final enactment is aborted for reasons that can only be assumed by the reader. Also, the mother figure in Șabrī Mūsās "Benevolence," the unequivocal voice of traditional protector of family honor, is split into two mother figures in "The Ashes." The first is Hassān's own mother, who oversees the family duty by guiding her son to adhere to the rules and regulations that traditional society imposes on the exacting of revenge. The second is the mother of the saved child, who seeks to protect her home and family by applying the rules and regulations of extending hospitality towards the stranger. Hassān thus finds himself caught inside the hospitality/revenge binary, and his ultimate decision to put an end to the revenge cycle constitutes a perversion of the traditional course of action. The opening scene of the crossing of the Nile may then be read as a symbolic foreshadowing that the story will not end as expected. Mahmūd al-Badawī inverts—or perverts the traditional paradigm with the final subversive act of not taking revenge as Hassān turns his back on his traditional familial duties.

Story 3. "Hịṭān 'äliyah" ("Within the Walls") by Idwār al-Kharrāt, 1954-195512

A young widow returns to her mother's house after the death of her older, brutish husband, but refuses to conform to traditional village mores with the excuse that she is no longer a virgin. Her Coptic family are well-to-do merchants and land owners who sent several of their sons to be educated in Cairo where some have settled.

News spreads of her relationship with a Muslim peasant who works on a piece of land she inherited and who comes to her house and even meddles in family business. Her cousin Zikri, the family patriarch, sends word for her to meet him in the orchard to settle the season's accounts with cousins Buktor and Shafiq. She relishes the thought of returning to her childhood romps, with hopes of obtaining some of her rightful earnings and bringing some fruit home to her mother.

12 Idwār al-Kharrāṭ, "Hịṭān 'āliyah," in Hītān 'āliyah: majmūeat qiṣaṣ (Cairo: Idwār al-Kharrāṭ at Mațba at Ațlas, 1968), pp. 7-18; English translation: "Within the Walls," tr. Denys JohnsonDavies, in Denys Johnson-Davies, Egyptian Short Stories (London: Heinemann, 1978), pp. $15-29$. 
When she finds herself facing the Nile, she steps down from the road along the bank to the ferry that will carry her across the river and to the family orchard. As she approaches, fear grips her heart: she feels she is passing from a familiar world into an unknown one, where danger lies in wait for her, and that "this river would fling her on to this land and abandon her there; it would reclaim for itself that freedom, that release, that sense of expansion it had momentarily given her, and would go once more on its way, unfathomed, to its destiny which was not that of man." ${ }^{33}$

She reaches the wall of the orchard, and her cousins embrace her with customary hospitality and proceed to distribute the profits. The sight of the blindfolded water buffalo going around in circles haunts her, prompting her to see in her cousins facets of the patriarchal system that had come to dominate her life: Buktor, strong and dignified, had infused in her respect and fear; Shafiq, who gave up city life to return to the village and the galabiyya, was responsible for her marriage, but became lustful and contemptuous of her; and Zikri, head of the family, who treated her with paternal gentility. They settle accounts and she ends up with only a handful of fruits. Suddenly, she notices the shed for the first time. After she goes in, the three enter and surround her, Shafiq sweating, Zikri towering and distant, Buktor like a priest in a church, "in his brown face lay the noble resolve of a crusader, the hideousness of the sentence and an inevitability that was absolute and from which the idea of flight did not occur to her, for it crushed all resistance."14 They strangle her, drop her on the ground, and go out and have a cigarette.

"Within the Walls" parallels "Benevolence" in its basic premise_-girl committing a crime of honor (jarimat sharaf) for which the male members of her family exact their revenge. However, the hospitality and revenge paradigm here expands into broader social binaries as male/female, urban/rural, and Muslim/Coptic tensions are embedded into the story. Haniyya, the protagonist, is a young, sexually active widow, still subject to codes of honor, and thus a threat to the patriline and its attendant implications of power. She had performed her filial duties by getting married but has the fortune of widowhood, which seemed to afford her a degree of independence, especially as she has no father or brothers. Also, as her father's sole heir, she has a right to the yield and a say in the management of the land. Her city habits, dress, comportment, and attitude threaten the traditional way of life; and her affair with a Muslim farmhand transgresses the religious and socio-economic boundaries that maintain the precarious balance in a potentially explosive and divisive

13 Kharrat, "Within the Walls," p. 22.

${ }^{14}$ Kharrat, "Within the Walls," p. 27. 
society. Her family's respectful reception of her into the clan must be complemented with her revenge killing as a way to protect its collective interests. Her crimes are not against them as individuals, but as a family, a business, and a church: her final execution is replete with Christian symbolism.

\section{Story 4. "Shāhid al-malik" ("State’s Witness") by Muḥammad Husayn Haykal, $1955^{15}$}

This story is a fictional account (presented as a realist rendering of a story told to the narrator, as mentioned in a postscript to the story) of the 1919 uprisings in Egypt against the British. A prosperous aristocrat is arrested for conspiring against the government and hires a famous English lawyer to defend him. At first, he resists any attempts to betray the cause, proud of having done a noble deed to free his country. After time in jail, and coaxed by prosecutors who entrap him, he decides to testify for the state, is pardoned, and protected through a witness protection program. Many Egyptians are executed; the two who are not, both fallähin, go back to their villages to heroes' welcomes. In contrast, when the aristocrat - a free man accompanied by two armed guards-returns to his village to take refuge, he is received with icy stares and is cold-shouldered by the villagers. He builds a wall around his house for protection.

During Ramadan, in an attempt to curry favor with his neighbors, he sets up a table for food and refreshment to greet passersby who cannot make it home in time for the iftär. No one partakes, except an old acquaintance of his who comes and chats with him, possibly as a decoy for the events to follow. This sole 'guest' only accepts dates and water (in keeping with Prophetic tradition?) in a prescribed ritual of (traditional) village host/guest protocol.

One evening, as a mob of farmers are returning home from the fields, carrying their axes and surrounded by their water buffaloes and donkeys, four masked men (mulaththamin) emerge from their midst and use their rifles to kill the state's witness. The two guards, who were breaking their fast inside the house, claim not to have heard a sound, and none of the farmers or villagers comes forth with any knowledge of the murderers' identities. Their silence is in stark contrast to the aristocrat's snitching.

As the news spreads quickly throughout the village, women ululate, and the ritual of ancient tribal revenge is reenacted as the mother of one of the executed men jumps on the body of the deceased and bites him. When the

\footnotetext{
${ }_{15}$ Muhammad Ḥusayn Haykal, Qișaș mișriyyah (Cairo: Dār al-Ma ārif, 1965), pp. 93-106 (first published in the literary magazine al-Musawwar in 1955).
} 
British authorities come to investigate they fail to find the culprits. The family members of the treasonous aristocrat are eventually forced to sell their property, change their names, and move to the anonymity of Cairo.

The hospitality / revenge binary is inscribed onto the national level with Egypt's struggle for independence from colonial rule. The evocation of a British-supported Egyptian government and its mass executions of native sons in retaliation for political resistance to foreign rule begins the revenge cycle. More significantly the story reworks religious imagery, not only to articulate traditional values and nationalist sentiment, but to define, explain, legitimize, and sanctify the exacting of revenge within the context of ancient local tribal vendettas. The rituals of Ramadan, from breaking the fast with water and dates to extending hospitality to the needy or wayfarers, enhances the justice and righteousness of the village's reaction to the aristocrat. The woman's biting of the deceased conjures images of the Battle of Uhud in 625 when Hind, wife of the Meccan leader, Abū Sufyān, tore the liver from the body of Muhammad's slain uncle, Hamzah, and bit into it in a ritualized enactment of revenge.

The expulsion of the protagonist from Cairo, the iniquitous metropolis of colonial rule, the locus of negotiable, foreign identities, corrupt Western ways, and ultimately national betrayal, is paired with the return to the village, with its evocation as the source of host/guest rituals being parallel to justice and loyalty to the homeland. The extended imagery of farmers tilling the soil, the national sustenance enriched by the Nile River, and the silent complicity of the bodyguards and the village elders, all implicate the collective as equally responsive to an ancient code that begins with the restoration of balance and justice to the community.

\section{Story 5. "al-Hāris" ("The Guard") by Maḥmūd al-Badawī, $1974^{16}$}

On 9 October 1973, a regional security officer is delegated to escort to Cairo a female Israeli pilot who has been shot down but has landed relatively unscathed on a rural farm. Boarding a train run down with broken windows, he scrambles to find a car in acceptable condition to accommodate her. He opens and closes a window when the air grows stuffy or windy, and takes pride in being able to protect her: "I took comfort in the fact that her life and safety were in my hands as her guard. I treated her gently from the beginning, and I kept the angry crowds away from her." Indeed, when he looks at her, he sees her as a woman, noticing for example, that her form-fitting

16 Mạ̣mūd al-Badawīs "al-Hāris," in al-Badawī, Qiṣaṣ min al-rîf, pp. 214-226. 
uniform reveals her thighs and breasts, and the feminine way in which she brushes off the dirt and mud. When he asks if she has any bruises she replies that she only has a slightly sprained ankle and he assures her that it will be treated. She tells him she was on a reconnaissance mission when a rocket hit her plane. She tells him she was born in Romania, and he remembers a photo of a happy, peaceful Romanian family he once saw: it is his attempt to understand her. But in a sudden incongruous outburst, he lashes out at her, and accuses her and her country of bearing sole responsibility for the war.

After some time he makes room for her and asks her if she would like to sleep for a while. She replies she is too hungry to sleep and he buys her something at the next stop in Dayrūt. The air is dirty and humid and dust flies in their faces, but he gets her food from a local canteen. She asks where he learned Hebrew so well and he replies that he grew up in a town that had a Jewish quarter. He tells her he's been sick and hasn't slept, but it is she who curls up to go to sleep. At Dayrūt he buys her juice. As he looks out beyond the canal at the darkness, a voice on the radio announces Egypt's successes in the fighting. In another outburst, he abruptly asks her to stand and he frisks her again, fearing they may not have checked her sufficiently. She responds to the rules of etiquette, as the perfect guest would, saying "tafaḍdal!"

As he touches her body, he convinces himself that he feels nothing sexual. He strains to keep control and maintain his dignity, and when she notices his cold detachment, she retracts, embarrassed. In this psychological battle of the sexes, it is she who is defeated. He falls asleep and dreams that she escapes to a court where she is sentenced to prison. The dream wakes him and as he shouts out he notices her standing; she tells him she needs to go to the WC. He escorts her and tells her to leave the door partly open, but his gentlemanliness gets the better of him and he shuts it. Later, they pass the cities of Minya, Samalūt, Banī Mazār and approach Maghāgha, all along the Nile, all of which he knows without having to read the signs.

After a while, having dozed off again, he awakes and notices she's gone. He is stricken with fear but maintains his composure. He rushes out and spots her escaping and running through a fence and onto a field. He focuses on her uniform-as if to remind himself that she is his prisoner-and he sees her passing the clover fields in the direction of the cornfields where she can easily hide. Then, she falls out of sight. He thinks of the shame and dishonor of an armed Egyptian officer (dābit) losing an unarmed Israeli girl (fatāt), and pondering this, decides not to use his wireless radio out of shame. He runs out onto the field, fires three shots, and hears her screaming, begging him not to shoot. He sees her lying face down in a ditch with her hands over her head. He cuffs her and takes her back, passing the heaps of dung that line the fields, crossing the canal, and reaching the train. Covered in mud she stares 
at him with hatred. At the station he removes her cuffs and she bursts into tears, sad and defeated.

His ambivalent sympathies flow, for her and for who she could have beenwife, teacher, physician, agent of positive force for her people-and against her country, one that made her into a destructive demon. He thinks of all the villages and towns of Egypt- the implied Nile comes into view in its explicit images:

I could see the sails of the boats along the river with their masts waving from afar against the dark sky like flags. They were drifting peacefully with no thought of war. And up ahead loomed the sight of the small station where anger and love wrestled one another, the love of life and the anger of revenge. (226)

\section{III}

Stories 1 and 2, "Benevolence" and "The Ashes," establish the traditional paradigm and its inversion, i.e., the exacting and repudiation of revenge, in its most primitive setting. In either case, the treatment of the hospitality/revenge binary is best read from the authorial point of view, urban, modern, and arguably Westernized, that seeks to interrogate the exacting of revenge for the common good. The description of the passerby as a professional robber and killer in "Benevolence" complicates the binary. In the eyes of the mother, and by extension the traditional village, he is the hero, but to the author and reader his depiction presents an adversarial view to both hospitality and revenge, whereby his professional trade questions the sanctity and righteousness of the duty of revenge. Also, the mellowing of the avenger's heart in "The Ashes" in light of greater tragedies neglects the duty of exacting revenge, reflecting a modern sensibility.

Story 3, "Within the Walls," expands the physical and social boundaries of the hospitality/revenge binary beyond the confines of the familiar rural archetype, weaving it into more complicated layers of urban/rural, Coptic/Muslim, and male/female tensions. The character of Haniyya, especially, gives voice to a modern, feminist defiance toward traditional patriarchal, religious, social, and economic injustices, which the hospitality/revenge binary is so effective in exposing. Story 4, "State's Witness," appropriates the binary onto the national resistance movement against colonial rule and the struggle for independence, exposing the rifts that divide Egyptians, pitting puppet government officials, collaborators and colonial sympathizers against loyal nationalists.

Finally, story 5, "The Guard," takes the hospitality/hostility binary beyond the national borders and into international territory, i.e., the Arab-Israeli conflict. The story evolves around the chance encounter between two people 
in confined quarters to examine the relationship between two nations-and two nationalisms-at war. The hospitality and revenge pairing appears in stark realistic and caricatured strokes as real-life events, dates, and places mix with fantasy, emotion, and stereotype. The extending of hospitality and the exacting of revenge, normally cast between two parties on equal footinghere Egypt and Israel-are problematized with the unequal pairing of an armed male officer and his unarmed female captive. The lopsidedness of the pairing is accentuated by the officer's ability to articulate his and his nation's political views while she, as prisoner, is silenced. However, the sanctity and righteousness of his positions, which stake claims to peace, justice, and tolerance, stand in stark contrast to the protagonist's own concerns with hospitality, the unruliness of the crowds, and the filth and squalor of the train and the train stations. With the implication of Israel's vast military and technological superiority in the background, "The Guard" may be read as an insightful, soul-searching and critical examination of the self, telling us as much about Egypt as Self as it does about Israel as Other. This is done most effectively through the linkage of hospitality and hostility.

The five short stories briefly outlined and discussed proffer fictional hypotheses in which improbable, melodramatic situations resonate with some of the stark realities of traditional Egyptian rural life. Their power as discreet texts rests upon a skillful use of literary techniques combined with the uncanny ability to delve into the inner recesses of the individual and collective psyche. Above all, they draw attention to the ways in which their society governs itself by its own devices, especially in times of chaos and uncertainty. As Hayden White reminds us, "narrative in general, from the folk tale to the novel, from the annal to fully realized "history" has to do with the topics of law, legality, legitimacy, or, more generally, authority." 17

I offer five preliminary conclusions regarding the themes of hospitality and revenge in these stories:

First: "hospitality" and "revenge" as literary topoi complement each other, especially when reading them with Clifford Geertz as "social, legal, psychological, economic structures by means of which individuals or groups of individuals guide their behavior." ${ }^{18}$ Both are constituent parts of collective social behavior that define human relationships from the micro to the macro levels.

${ }^{17}$ Hayden White, "The Value of Narrativity in the Representation of Reality," Critical Inquiry 7/1 (1980), pp. 5-27, at p. 17.

${ }_{18}$ Clifford Geertz, "Thick Description: Toward an Interpretive Theory of Culture," in The Interpretation of Cultures: selected essays (New York: Basic Books, 1973), p. 11. 
Second: their literary (fictional) configurations read closely to their anthropological explications. They subject themselves to rules and regulations in which all parties involved are conscious but which they may choose to obey or subvert. Acts of hospitality and revenge begin with individual agency but become collective actions, reciprocal, negotiable, and accountable, with wide social ramifications. All acts of hospitality and revenge reflect back on the family, the clan or community, the sect, the village, and the nation, and they are held to society's norms and values, often arbitrated and supervised by more powerful forces.

Third: despite the collective implications they engender, hospitality and revenge as literary themes tap into basic human emotions and elicit instinctual responses that may unite or separate individuals in their shared humanity. They feed on and manipulate tensions between love and hate, fear and aggression, jealousy and desire, hope and despair, allowing the writer to engage in equal measure between romantic and realist modes of creative writing, while exploring psychological and social forces operating below the surface. In other words, the hospitality/revenge binary is capable of covering the full gamut of human experience.

Fourth: the Nile features prominently as signifier of the Egyptian nation. It unites villages to small towns and to big cities; it is the source of sustenance to farmers and city dwellers alike; and it unites all Egyptians in a shared space and a common history. The Nile in these stories may be read as the vertical line of tradition, constancy and stability against which the horizontal lines of subversion, mobility and change traverse.

Fifth: these five stories, read as I have sequenced them, can be shown to follow a line of progression in which the hospitality/revenge binary begins at the individual level and expands to the familial, tribal, sectarian, national and finally international level. They encompass what Northrop Frye describes as "historical facts and fictions that have stuck together, coagulating into a grand mythology with a shared language, reference, allusion, belief, and tradition... covering a society's view of its past, present and future, its relation to its gods and its neighbors, its traditions, its social and religious duties, and its ultimate destiny." ${ }^{\prime \prime}$

\footnotetext{
19 Northrop Frye, The Critical Path (Bloomington: Indiana University Press, 1973), pp. $35-36$.
} 
Copyright of Journal of Arabic Literature is the property of Brill Academic Publishers and its content may not be copied or emailed to multiple sites or posted to a listserv without the copyright holder's express written permission. However, users may print, download, or email articles for individual use. 